\title{
『十誦律』「雑誦」における「狂心等の解釈」 ——『婆沙論』から影響を受けた可能性をめぐって—
}

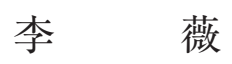

『十誦律』の「雑誦」という部分は第十誦の末尾にある罪の判例集（Vinitaka）で ある ${ }^{1)}$. ほかの五部広律にも，これに対応する判例集が見られる。これについて は, 多数の研究者によって, 認められている ${ }^{2)}$. しかし他の広律と違って, 『十誦 律』のこの部分には，判例だけではなく，解釈の表現もその中に挟み込まれてい る. その中の一つが，本論で調査対象にする「狂心等の解釈」である。この表現 は他の広律の対応する部分には見当たらず, 『十誦律』特有の表現であると考えら れるが, 相似する解釈が『阿毘達磨大毘婆沙論』（以下『婆沙論』と略称）などのア ビダルマ論書に見出される.

『十誦律』と『婆沙論』の関係について, 佐々木閑は「婆沙論と律」で, 『婆沙 論』に引用される毘奈耶（律）の例を調査した，それだけではなく，逆方向の引 用パターン，すなわち，アビダルマ論書から律への影響も指摘している。 また， 著書『インド仏教変移論——ぜ仏教は多様化したのか』にも，『十誦律』の「優 波離問法中雑事」・「比尼誦」など附録部分にはアビダルマ論書で新しく現れてき た概念が導入されたという指摘もある3).

本論では, この「狂心等の解釈」をめぐって, 『婆沙論』等のアビダルマ論書と 『十誦律』の相互関係について検討する.

まず, 『十誦律』の関連記述を説明する。『十誦律』の「狂心等の解釈」は「雑誦」 判例集の冒頭にある。内容は各律蔵経分別に共通する比丘の不犯（anāpatti）にな る条件「最初の犯行者 (ādikammikassa), 狂者 (ummattakassa), 乱心者 (khittacittassa), 苦痛者 (vedanātțassa)」という四つの条件に対する解釈である.これら解釈は問答 の形として登場する。すなわち, 比丘がこの四つの不犯条件について仏陀に聞く, そして，仏陀はそれぞれにこたえる，本論で調査対象にするのがこの中にある「狂 心と乱心」の解釈である.

『十誦律』には, 狂人と散乱心は区別され, それぞれ五種類に分けられている. 
すなわち，狂は，(1) 親類が死に尽し，(2) 財物を失い尽し, (3) 畑と人民を失い尽 し, (4) 四大が錯乱し, (5) 先世の業報を受けるとする五種類の人である. 散乱心の 原因は，(1) 非人によって打たれたため, (2) 非人によって心を散乱されたため, 或 いは (3) 非人によって心・精・気を食べられたため, 或いは (4) 四大錯乱したため, 或いは (5) 先世の業報のためという五つの原因である (T23, 424b-424c $)^{4)}$. この解釈 の中に,「(4)四大が錯乱した」と「(5) 先世の業報」は両者に一致する部分である.

前に述べたように，他の広律の対応箇所には，これらの解釈は見当たらないの で,『十誦律』にあることは, 後から挿入された可能性を示していると考えられ る.さらに,「散乱心」の解釈の中に,「比尼中に散乱心は不犯なりと説く」(比尼 中説散乱心不犯, T23,424b26）という表現がある.この表現によって,「散乱心」と いう解釈が新しく加えられたと考えられる.もし元々律にある表現ならば,「比尼 中説」といわないはずだからである.

つぎに，アビダルマ論書を説明する。『発智論』には，心狂乱は四つの原因に よって起こると説かれている. すなわち, (1) 非人の悪色からの恐怖による, (2) 非 人に打たれたことによる, (3) 大種の錯乱による, (4) 先業の異熟による, 四つの原 因である (T26,981a).この四つは『十誦律』の散乱心の記述の中にも存在する.

『婆沙論』は, 『発智論』と同じょうに, 心狂乱が主に四種の原因で起こると解 釈しているが，異なる点が二つある.

一つは, 『発智論』とは異なり,「有る五種類因縁」の説が書かれている（有説. 狂乱由五種縁．前四如前．愁憂第五 $)^{5)}$.この説によれば，息子を失う憂愁になるのも 狂乱の因縁であることになる。

もう一つは，心狂乱を解釈する理由が説かれている，つまり，阿含経と律のた めであると説かれている，阿含経には，婆羅門女婆私が六人の息子を失って，狂 乱するという話がある，また，律にも「室利筏蹉が狂乱した」話もあり，「苦受に 逼られて若し心が狂乱せしときと, 及び初業位とには皆, 犯有ること無し」とい う話もある ${ }^{6}$. しかし，阿含経と律とも，話があるだけで，詳しい説明が書かれ ていない，それ故，ここで狂乱について，より詳しく解釈するのである7).

『俱舎論』にも心狂の原因は五種類あると説かれている。 これは, 『婆沙論』で 説かれた「有る説」と一致する，また，『順正理論』は『俱舎論』と同じく，五種 類の心狂乱が説かれている8).

上記のアビダルマ論書の内容を整理すると, 心狂乱の因縁に関する記述はアビ ダルマ論書では変化していることがわかる. 最初, 『発智論』に四種類の因縁が書 
かれている、『婆沙論』に, この四種類の上に，「息子を失う愁憂による」が新し く加えられ，五種類因縁を主張している「有る説」が登場した，後に『俱舎論』 と『順正理論』になると, この五種類因縁の説は正統説になったという変遷過程 を想定することができる.

また, 『十誦律』の記述と合わせて考えると, 『十誦律』には, 狂と散乱心がそ れぞれ分類されている．両者をアビダルマ論書にある「心狂乱」に対応させるこ とができる.

具体的には, 『十誦律』「狂」の解釈の中, 「(4)四大が錯乱し」,「(5) 先世の業報 を受ける」はアビダルマ論書の記述と一致し，その「1 親類が死に尽し」は『婆 沙論』の「別説」及び『俱舎論』の五種類説と一致している．『十誦律』「散乱心」 解釈の中の四種類解釈 (1) 非人に打たれたため, (2) 非人によって心が散乱させられたた め, (4)四大錯乱したため, (5) 先世の業報のため) は, 『発智論』及び『婆沙論』の「心 狂乱」の四種類説と一致する。『十誦律』の「散乱心」は,「狂」より, アビダル マ論書「心狂乱」に合致することもいえる.

さて, 『十誦律』とアビダルマ論書の関係性から考えると, この相似する解釈 （特に『十誦律』の散乱心）は『十誦律』がアビダルマ論書に影響を与えたか或いは アビダルマ論書が『十誦律』に逆方向に影響を与えたかという問題を検討しなけ ればならない.

結論から言うと，アビダルマ論書が『十誦律』に影響を与えたと考える．理由 は以下のとおりである.

理由の一つは, すでに述べたように, 『十誦律』には, この解釈は後から加えら れたと考えられ，他の五部広律に対応する箇所には，この解釈は見当たらないか らである。

さらに,『十誦律』「散乱心」の解釈中の「比尼中に散乱心は不犯なりと説く」 （此尼中説散乱心不犯，T23,424b）という表現からみると，この解釈は元々律に存在 しなかったと考えられる. なぜかというと, もし律の中の話であるならば,「比尼 中」というはずがない.

もう一つの理由は, 『婆沙論』に書かれている「心狂乱を解釈する理由」であ る.つまり，『婆沙論』には，「律の中に，苦痛・心狂乱・初作不犯が説かれると いえども, 詳しく説明が書かれていないから, ここに狂乱をより詳しく解釈する のである」(毘奈耶中又作是説. 苦受所逼若心狂乱. 及初業位皆無有犯. 契経毘奈耶雖作 是説. 而不広弁. 今為広弁故作斯論, T27, 658a）という理由である.つまり, 『婆沙 
論』が根拠としていた律蔵の中に，狂乱に関する解釈が存在していないというこ とになる。もし律に，心狂乱の解釈がすでに存在していたとするならば，『婆沙 論』にわざわざもう一度詳しく同様の説明をする必要がないからである.

よって, 『十誦律』のこの解釈は, 『婆沙論』などアビダルマ論書の影響をうけ て，後から入れられた記述であると考えられる。

1）『十誦律』に扔いては, 「淫戒・偷盗戒・断人命戒・妄語戒・つまり四波羅夷罪及び僧 残第一条・僧残第二条・僧残第五条」についての罪の判定事例が列挙されている.

2）龍口明生 1989, 佐藤密雄 1993, 24, 平川彰 1960, 659-662, 上田天瑞 1931, 長井真琴 1922, 36 参照. 3）佐々木閑 2000a, 2000b, 118-121 参照. 4）また, 『薩婆多 部毘尼摩得勒伽』にも, 『十誦律』と相似する表現がある. チベット語「根本説一切有部 律」の Uttaragrantha の'Dul bar byed pa（Vinītaka）中にも類似する表現がある. Shayne Clarke 2016 参照. 5) 『婆沙論』(T27, 658a)。 6）木村泰賢他 1932, 223 参 照. 7)『婆沙論』(T27,658). 8)『説一切有部順正理論』(T29, 572b).

〈参考文献〉

上田天瑞 1931「巴利律蔵と漢訳律蔵との比較研究——特に四波羅夷につき」『宗教研究』 新 8 (6): 53-81.

木村泰賢他訳 1932『国訳一切経 毘曇部』13 (『婆沙論』), 大東出版社. 木村泰賢・荻原雲来訳 1920 『国訳大藏経 論部』12（『俱舎論』）, 国民文庫刊行会. 佐々木閑 2000a「婆沙論と律」『印度学仏教学研究』49 (1): 421-413.

——2000b『インド仏教変移論——なぜ仏教は多様化したのか』大藏出版. 桜部建・加治洋一校註 1996 『発智論』1, 新国訳大蔵経 15 , 大蔵出版. 佐藤密雄 1954「十誦律の訂正について」『印度学仏教学研究』2 (2): 580-584. ——1993『原始仏教教団の研究』山喜房仏書林.

長井真琴 1922『根本仏典の研究』天地書房.

西義雄・坂本幸男訳 1934『国訳一切経 毘曇部』18（『阿毘曇八揵度論』）, 大東出版社. 平川彰 1960 『律蔵の研究』山喜房仏書林.

龍口明生 1989 「『四分律』調部に関する問題点」『印度学仏教学研究』37 (2): 552-558.

Shayne Clarke. 2016. "The 'Dul bar byed pa (Vinītaka) Case-Law Section of the Mūlasarvāstivādin Uttaragrantha: Sources for Guṇaprabha's Vinayasūtra and Indian Buddhist Attitudes towards Sex and Sexuality." Journal of the International College for Postgraduate Buddhist Studies 20: 49-196.

〈キーワード〉『十誦律』, 狂, 散乱心, アビダルマ論書 